\title{
INFLAMMATORY RESPONSE FOLLOWING PERIPHERAL ENDOVASCULAR TREATMENT CORRELATES WITH THE EXTENT OF PERIPROCEDURAL ARTERIAL INJURY
}

\author{
Tajana Turk ${ }^{1}$, Otmar Rubin ${ }^{1}$, Gordan Šarić ${ }^{1}$, Tonći Mišević ${ }^{1}$, Vjekoslav Kopačin ${ }^{1}$, \\ Damir Kovač ${ }^{2}$, Vedran Ivković , Vedran Farkaš ${ }^{2}$ and Vatroslav Šerić ${ }^{3}$ \\ ${ }^{1}$ Department of Diagnostic and Interventional Radiology, Faculty of Medicine, \\ Josip Juraj Strossmayer University of Osijek, Osijek, Croatia; ${ }^{2}$ Department of Surgery, \\ Faculty of Medicine, Josip Juraj Strossmayer University of Osijek, Osijek, Croatia; \\ ${ }^{3}$ Department of Chemistry, Biochemistry and Clinical Chemistry, Faculty of Medicine, \\ Josip Juraj Strossmayer University of Osijek, Osijek, Croatia
}

\begin{abstract}
SUMMARY - The aim was to examine whether the postprocedural change in C-reactive protein (CRP) and fibrinogen levels was associated with the extent of periprocedural arterial injury caused by endovascular treatment (EVT). The study recruited 71 patients undergoing EVT. Eighty-four patients that underwent angiography served as a control group. CRP and fibrinogen were measured at baseline, and at 8,24 and 48 hours following the procedure. In all experimental group patients, lesion complexity, percutaneous transluminal angioplasty (PTA) treated segment length, balloon inflation time and stented segment length were recorded. There was significant increase in plasma CRP and fibrinogen levels 48 hours following EVT $(\mathrm{p}<0.001)$. There was no significant difference in CRP and fibrinogen levels among different TASC groups. CRP levels were significantly higher in stent subgroup compared to PTA subgroup. Significant positive correlation was found between PTA treated segment length and CRP increase between 8 and 24 hours following EVT ( $r=0.313, p=0.02)$, balloon inflation time and CRP increase in the aforementioned time frame $(r=0.270, p=0.03)$, as well as between CRP increase at 8 hours and stented segment length $(\mathrm{r}=0.535, \mathrm{p}=0.01)$. This study showed that the arterial injury caused by EVT reflected on the level of inflammatory biomarkers.
\end{abstract}

Key words: C-reactive protein; Fibrinogen; Stents; Angiography; Endovascular procedures; Angioplasty

\section{Introduction}

Despite recent technical advances that have improved endovascular treatment (EVT) for peripheral arterial disease (PAD), neointimal hyperplasia and subsequent restenosis remain major culprits for failure. Balloon angioplasty leads to atherosclerotic plaque

Correspondence to: Tajana Turk, $M D$, Department of Diagnostic and Interventional Radiology, Osijek University Hospital Centre, J. Huttlera 4, HR-31000 Osijek, Croatia

E-mail: turk.tajana@gmail.com

Received July 14, 2017, accepted September 15, 2017 rupture, exposure of its lipid rich core and activation of blood components ${ }^{1}$. Stent implantation causes immediate biological response of protein, fibrinogen and blood cell deposition between stent struts and proliferation of granulation tissue and vascular smooth muscle cells ${ }^{2}$. This process of endothelial healing leads to neointimal hyperplasia, which correlates with the extent of arterial wall injury ${ }^{3}$.

It has been reported that higher postprocedural levels of inflammatory biomarkers indicate a higher risk of restenosis ${ }^{4,5}$. Both $\mathrm{C}$-reactive protein (CRP) and fibrinogen have been established as biomarkers in 
Table 1. Patient characteristics

\begin{tabular}{|c|c|c|c|}
\hline & Control group & Study group & $p$ \\
\hline $\begin{array}{l}\text { Gender, } \mathrm{n}(\%): \\
\text { male } \\
\text { female }\end{array}$ & $\begin{array}{l}64(76.2) \\
20(23.8) \\
\end{array}$ & $\begin{array}{l}52(73.2) \\
19(26.8)\end{array}$ & $0.71^{*}$ \\
\hline $\begin{array}{l}\text { Age (yrs), median } \\
(25 \%-75 \%)\end{array}$ & $\begin{array}{l}64.5 \\
(58-71.8)\end{array}$ & \begin{tabular}{|l|}
62 \\
$(58-69)$
\end{tabular} & $0.29^{\dagger}$ \\
\hline $\begin{array}{l}\text { Fontaine stage, n (\%): } \\
\text { II A } \\
\text { II B } \\
\text { III } \\
\text { IV }\end{array}$ & $\begin{array}{l}17(20.2) \\
58(69) \\
5(6) \\
4(4.8) \\
\end{array}$ & $\begin{array}{l}17(23.9) \\
49(69) \\
3(4.2) \\
2(2.8)\end{array}$ & $0.84^{*}$ \\
\hline $\begin{array}{l}\text { TASC II lesion: } \\
\text { A } \\
\text { B } \\
\text { C } \\
\text { D }\end{array}$ & & $\begin{array}{l}38(59.4) \\
21(32.8) \\
5(7.8) \\
0\end{array}$ & \\
\hline DM, n (\%) & $30(35.7)$ & $26(36.6)$ & $>0.99^{*}$ \\
\hline Hypertension, n (\%) & $55(65.5)$ & $51(71.8)$ & $0.49^{*}$ \\
\hline CVD, n (\%) & $14(16.7)$ & $10(14.1)$ & $0.82^{*}$ \\
\hline CAD, n (\%) & $16(19)$ & $12(16.9)$ & $0.84^{*}$ \\
\hline Smoking, n (\%) & $45(53.6)$ & $35(49.3)$ & $0.63^{*}$ \\
\hline Dyslipidemia, n (\%) & $66(95.7)$ & $45(77.6)$ & 0.003* \\
\hline $\begin{array}{l}\text { Volume of contrast medium used } \\
(\mathrm{mL}), \text { median }(25 \%-75 \%)\end{array}$ & $\begin{array}{l}110 \\
(93.5-127.5)\end{array}$ & $\begin{array}{l}140 \\
(80-180)\end{array}$ & $0.02^{+}$ \\
\hline $\begin{array}{l}\text { Outcome, } \mathrm{n}(\%) \text { : } \\
\text { PTA } \\
\text { stenting }\end{array}$ & & $\begin{array}{l}44(72) \\
27(38)\end{array}$ & \\
\hline $\begin{array}{l}\text { Balloon inflation time }(\mathrm{s}) \text {, } \\
\text { median }(25 \%-75 \%)\end{array}$ & - & $\begin{array}{l}360 \\
(180-431.3) \\
\end{array}$ & - \\
\hline $\begin{array}{l}\text { PTA treated segment length }(\mathrm{cm}) \text {, } \\
\text { median }(25 \%-75 \%)\end{array}$ & - & $\begin{array}{l}8 \\
(6-15) \\
\end{array}$ & - \\
\hline $\begin{array}{l}\text { Stented segment length }(\mathrm{cm}) \\
\text { median }(25 \%-75 \%)\end{array}$ & - & $\begin{array}{l}5 \\
(4-6) \\
\end{array}$ & - \\
\hline
\end{tabular}

*Fisher exact test; ${ }^{\dagger}$ Mann Whitney $\mathrm{U}$ test; CAD = coronary artery disease; CVD = cerebrovascular disease; $\mathrm{DM}=$ diabetes mellitus; $\mathrm{PTA}=$ percutaneous transluminal angioplasty; TASC II = TransAtlantic Inter-Society Consensus Document on Management of Peripheral Arterial Disease

atherosclerosis, but their exact role remains controversial $^{6}$. Although CRP is mainly synthesized in the liver, it is also produced by vascular smooth muscle cells and macrophages in the atherosclerotic plaque ${ }^{7,8}$. Plasma concentration of CRP correlates with the level of its synthesis ${ }^{9}$. In vitro studies have shown that mechanical strain leads to local CRP expression in human arteries ${ }^{10}$. Fibrinogen was found to be associated with both the onset and progression of PAD ${ }^{11,12}$. Apart from being the key determinant of blood viscosity and throm- bus formation, fibrinogen is also responsible for neointimal growth by stimulation of vascular smooth muscle cells ${ }^{13}$.

Although the correlation between postprocedural levels of inflammatory biomarkers and EVT has been investigated in several studies, the association with the extent of periprocedural arterial injury has not been completely elucidated.

The aim of this study was to examine whether the postprocedural change in CRP and fibrinogen levels 
was associated with the extent of periprocedural arterial injury measured by percutaneous transluminal angioplasty (PTA) treated segment length, balloon inflation time and stented segment length.

\section{Subjects and Methods}

\section{Study design}

This observational single-center cohort study was conducted at Department of Diagnostic and Interventional Radiology, Osijek University Hospital Centre, Osijek, Croatia between June 2014 and April 2017. Before enrolment, all patients provided their written informed consent. The study was approved by the Ethics Committee of the Osijek University Hospital Centre.

\section{Study population}

Patients were referred by vascular surgeon for diagnostic angiography and/or EVT for PAD. Seventyone patients who underwent technically successful PTA with or without stent implantation were recruited. Eighty-four patients who underwent diagnostic angiography of lower limbs during the same period served as a control group. Their demographic characteristics are listed in Table 1 . Fontaine classification ${ }^{14}$ was used to categorize the severity of PAD. The TransAtlantic Inter-Society Consensus Document on Management of Peripheral Arterial Disease (TASC II) ${ }^{15}$ classification was used to categorize the complexity of lesions to be treated. Patients on hemodialysis treatment, patients with malignant disease, those with a history of surgery, myocardial infarction or coronary endovascular intervention in the past 3 months or endovascular intervention on peripheral arteries in the last 2 weeks, patients on immunosuppressant therapy and those suffering from or treated for chronic inflammatory diseases, and patients with clinical or laboratory signs of acute infection ( $\mathrm{CRP} \geq 10 \mathrm{mg} / \mathrm{L}$ ) were excluded from the study. Patients who underwent any other form of EVT besides balloon angioplasty and bare metal stent implantation (such as drug coated balloon angioplasty, drug eluting stent implantation, stent graft implantation, thrombolysis, thrombectomy, etc.) were not included in the study.

\section{Methods}

Lower limb arteriography and interventional procedures were performed by an interventional radiolo- gist (T.T., O.R., G.S. or T.M.) using standardized protocol and femoral arterial ipsilateral or contralateral access. The procedures were performed on iliac and femoropopliteal arteries according to TASC II guidelines. PTA balloon and stent diameters and length were selected according to the vessel diameter and diseased segment length.

Stenting was performed in case of elastic recoil, flow-limiting dissection or residual stenosis greater than $30 \%$. During EVT, all patients received a bolus of 5000 IU of heparin intra-arterially. After EVT, all patients received $40 \mathrm{mg}$ of subcutaneous enoxaparine for three days. In all patients, localization and complexity of the lesion, balloon inflation time, PTA treated segment length, and stented segment length were recorded.

\section{Clinical data}

In all patients, demographic data and medical history were determined using a questionnaire and medical records. Hypertension was defined as blood pressure of $>130 / 90 \mathrm{~mm} \mathrm{Hg}$ or a history of treatment for hypertension. Dyslipidemia was defined as a serum high-density lipoprotein (HDL) level $<1 \mathrm{mmol} / \mathrm{L}$, low-density lipoprotein (LDL) level $>3 \mathrm{mmol} / \mathrm{L}$, cholesterol level $>5 \mathrm{mmol} / \mathrm{L}$, and triglyceride level $>1.7$ $\mathrm{mmol} / \mathrm{L}$. Diabetes mellitus was defined as having fasting blood glucose level $>6.4 \mathrm{mmol} / \mathrm{L}$ or hemoglobin $A_{1 c}>6 \%$ or a history of treatment with antidiabetic medications. Coronary artery disease was defined as a history of myocardial infarction, angina pectoris, or coronary revascularization procedures. Cerebrovascular disease was defined as a history of transient ischemic attacks, cerebral hemorrhage, stroke, or carotid artery revascularization procedure.

\section{Blood sampling}

Baseline peripheral venous blood samples were obtained from each patient before angiography or EVT, in the morning after overnight fast. Subsequently, venous blood samples were obtained at 8 hours, 24 hours and 48 hours after the procedure. CRP levels were measured by an immunoturbidimetric method (Olympus AU480, Beckman Coulter, Tokyo, Japan). Fibrinogen levels were measured by a coagulometric method (BCS XP, Siemens Healthcare Diagnostics, Marburg, Germany). Laboratory values were recorded for each patient and compared between the groups. 


\section{Statistical analysis}

Data were processed using descriptive statistical methods. Mann-Whitney and Kruskal-Wallis tests were used on sample comparison. Wilcoxon test and Friedman's test were used to detect differences between dependent samples. Spearman's rho test was used to determine the association between non-normally distributed variables. The level of significance was set at alpha of 0.05 . Statistical analysis was performed using MedCalc Statistical Software version 14.12.0 (MedCalc Software bvba, Ostend, Belgium; http://www.medcalc.org; 2014).

\section{Results}

The indication for EVT was mild intermittent claudication (Fontaine stage IIA) in 17 (23.9\%), moderate to severe claudication (Fontaine stage IIB) in 49 (69\%) and limb ischemia (Fontaine stages III and IV) in five (7\%) patients. Lesions to be treated were classified as TASC II A in 38 (59.4\%), TASC II B in 21 (32.8\%) and TASC II C in five (7.8\%) patients. There were no patients with TASC II D lesion. No complications occurred during or following EVT. PTA was performed in $44(72 \%)$ and stenting in $27(38 \%)$ patients. The median balloon inflation time during PTA was 360 seconds (s) (interquartile range [IQR] 180431.3). Balloon inflation time for a single patient was calculated as the sum of duration of all balloon inflations performed during vascular intervention. The median length of PTA treated segment was $8 \mathrm{~cm}$ (IQR 6-15) and the median stented segment length was 5 $\mathrm{cm}$ (IQR 4-6).
There was significant increase in both plasma CRP and fibrinogen levels in the first 48 hours following EVT $(p<0.001)$. The increase in CRP and fibrinogen levels was also recorded in the control group, but it was not statistically significant. CRP levels were significantly higher in the study group 24 hours following EVT compared to the control group 24 hours following angiography $(\mathrm{p}<0.05)$. No other statistically significant difference regarding CRP and fibrinogen levels was found between the groups at different time points (Table 2).

Among patients with different lesion complexity (Table 3), significant increase in both CRP and fibrinogen levels was noted in patients with lesions classified as TASC II A and B. Patients with TASC II C lesions showed significant increase in CRP $(\mathrm{p}<0.05)$, but not in plasma fibrinogen levels $(p>0.05)$. No significant difference in CRP and fibrinogen levels was found at examined time points following EVT between different TASC II groups.

Regarding the location of pathology, there was a significant postprocedural increase in plasma CRP and fibrinogen levels $(\mathrm{p}<0.001)$ in patients with femoropopliteal interventions and in patients with iliac interventions. However, there was no significant difference in postprocedural CRP and fibrinogen elevation between these two subgroups.

Significant increase in CRP $(\mathrm{p}<0.001)$ and fibrinogen $(\mathrm{p}=0.001)$ levels was found in the subgroup of $\mathrm{pa}^{-}$ tients who underwent PTA, as well as in the subgroup that underwent stenting $(\mathrm{p}<0.001)$ (Table 4). CRP levels were significantly higher $(\mathrm{p}=0.03)$ in the stent

Table 2. Plasma levels of $C R P(\mathrm{mg} / \mathrm{L})$ and fibrinogen $(\mathrm{g} / \mathrm{L})$ after angiography (control group) and endovascular treatment (study group)

\begin{tabular}{|c|c|c|c|c|c|c|}
\hline & \multicolumn{5}{|c|}{ Median (interquartile range) } & \multirow{2}{*}{$\mathrm{p}^{\dagger}$} \\
\hline & Control group & $\mathrm{p}^{*}$ & Study group & $\mathrm{p}^{*}$ & All patients & \\
\hline CRP 0 & $3(1.9-4.7)$ & \multirow{4}{*}{0.13} & $3.7(2.05-6)$ & \multirow{4}{*}{$<0.001$} & $3.2(1.9-5.18)$ & 0.17 \\
\hline CRP 8 h & $3.1(1.8-5.33)$ & & $3.7(1.9-6.75)$ & & $3.3(1.88-6)$ & 0.42 \\
\hline CRP $24 \mathrm{~h}$ & $4.75(2.83-6.8)$ & & $6.2(3.4-11.45)$ & & $5(2.9-9.4)$ & 0.03 \\
\hline CRP $48 \mathrm{~h}$ & $6.5(3.25-8.4)$ & & $9.1(4.3-17.7)$ & & $7.85(3.85-14.5)$ & 0.09 \\
\hline Fibrinogen 0 & $3.7(3.3-4.3)$ & \multirow{4}{*}{0.18} & $3.8(3.3-4.7)$ & \multirow{4}{*}{$<0.001$} & $3.8(3.3-4.5)$ & 0.38 \\
\hline Fibrinogen $8 \mathrm{~h}$ & $3.5(3.2-4.18)$ & & $3.6(3.13-4.1)$ & & $3.55(3.2-4.1)$ & 0.76 \\
\hline Fibrinogen $24 \mathrm{~h}$ & $3.8(3.33-4.68)$ & & $4(3.45-4.85)$ & & $3.9(3.4-4.7)$ & 0.42 \\
\hline Fibrinogen $48 \mathrm{~h}$ & $4.3(3.3-5.3)$ & & $4.3(3.7-5.2)$ & & $4.3(3.68-5.23)$ & 0.93 \\
\hline
\end{tabular}

${ }^{*}$ Friedman's test; ${ }^{\dagger}$ Mann Whitney $\mathrm{U}$ test; $\mathrm{CRP}=\mathrm{C}$-reactive protein 
Table 3. Correlation of plasma levels of $C R P(\mathrm{mg} / \mathrm{L})$ and fibrinogen $(\mathrm{g} / \mathrm{L})$ with lesion complexity according to TASC II classification

\begin{tabular}{|c|c|c|c|c|c|c|c|}
\hline & \multicolumn{6}{|c|}{ Median (interquartile range) } & \multirow{2}{*}{$\mathrm{p}^{\dagger}$} \\
\hline & TASC II A & $\mathrm{p}^{*}$ & TASC II B & $\mathrm{p}^{*}$ & TASC II C & $\mathrm{p}^{*}$ & \\
\hline CRP $8 \mathrm{~h}$ & $\begin{array}{l}3.8 \\
(2.5-7.3)\end{array}$ & \multirow{3}{*}{$<0.001$} & $\begin{array}{l}2.6 \\
(1.2-6.7)\end{array}$ & \multirow{3}{*}{0.001} & $\begin{array}{l}3.05 \\
(1.15-50.18)\end{array}$ & \multirow{3}{*}{0.03} & 0.32 \\
\hline CRP $24 \mathrm{~h}$ & $\begin{array}{l}6.2 \\
(3.7-12.45)\end{array}$ & & $\begin{array}{l}6.2 \\
(2.7-11.2)\end{array}$ & & $\begin{array}{l}6.35 \\
(3.75-63.78)\end{array}$ & & 0.64 \\
\hline CRP $48 \mathrm{~h}$ & \begin{tabular}{|l|}
8.75 \\
$(4.13-15.38)$
\end{tabular} & & $\begin{array}{l}9.1 \\
(5-25.1)\end{array}$ & & $\begin{array}{l}7.25 \\
(3.73-71.83)\end{array}$ & & 0.80 \\
\hline Fibrinogen $8 \mathrm{~h}$ & $\begin{array}{l}3.6 \\
(3.05-4)\end{array}$ & \multirow{3}{*}{$<0.001$} & $\begin{array}{l}3.7 \\
(3.23-4.35)\end{array}$ & \multirow{3}{*}{0.005} & $\begin{array}{l}4.1 \\
(3.7-6)\end{array}$ & \multirow{3}{*}{0.08} & 0.13 \\
\hline Fibrinogen $24 \mathrm{~h}$ & $\begin{array}{l}4 \\
(3.4-5.15)\end{array}$ & & $\begin{array}{l}4 \\
(3.6-4.65)\end{array}$ & & $\begin{array}{l}4.6 \\
(3.9-6.3)\end{array}$ & & 0.29 \\
\hline Fibrinogen $48 \mathrm{~h}$ & $\begin{array}{l}4.3 \\
(3.5-5.05)\end{array}$ & & $\begin{array}{l}4.8 \\
(3.68-5.43)\end{array}$ & & \begin{tabular}{|l|}
4.3 \\
$(4.3-5.4)$
\end{tabular} & & 0.51 \\
\hline
\end{tabular}

*Friedman's test; ${ }^{\top}$ Kruskal Wallis test; CRP = C-reactive protein; TASC II = Trans-Atlantic Inter-Society Consensus Document on Management of Peripheral Arterial Disease classification

Table 4. Plasma levels of CRP $(\mathrm{mg} / \mathrm{L})$ and fibrinogen $(\mathrm{g} / \mathrm{L})$ in patients undergoing $P T A$ and stent implantation

\begin{tabular}{|c|c|c|c|c|c|c|}
\hline & \multicolumn{5}{|c|}{ Median (interquartile range) } & \multirow{2}{*}{$\mathrm{p}^{\dagger}$} \\
\hline & PTA & $\mathrm{p}^{*}$ & Stent & $\mathrm{p}^{*}$ & Total EVT & \\
\hline CRP 0 & $\begin{array}{l}3.6 \\
(2-5.9)\end{array}$ & \multirow{4}{*}{$<0.001$} & $\begin{array}{l}4.6 \\
(2.13-7.65)\end{array}$ & \multirow{4}{*}{$<0.001$} & $\begin{array}{l}3.7 \\
(2.05-6)\end{array}$ & 0.33 \\
\hline CRP $8 \mathrm{~h}$ & $\begin{array}{l}3.3 \\
(1.65-5.75)\end{array}$ & & $\begin{array}{l}4.6 \\
(2.1-12)\end{array}$ & & $\begin{array}{l}3.7 \\
(1.9-6.75)\end{array}$ & 0.09 \\
\hline CRP $24 \mathrm{~h}$ & $\begin{array}{l}6.2 \\
(3.4-9.85) \\
\end{array}$ & & $\begin{array}{l}10.1 \\
(3.08-14.73)\end{array}$ & & $\begin{array}{l}6.2 \\
(3.4-11.45)\end{array}$ & 0.18 \\
\hline CRP 48 h & $\begin{array}{l}7 \\
(3.65-14.05)\end{array}$ & & $\begin{array}{l}12.75 \\
(8.05-23.88)\end{array}$ & & $\begin{array}{l}9.1 \\
(4.3-17.7)\end{array}$ & 0.03 \\
\hline Fibrinogen 0 & $\begin{array}{l}3.8 \\
(3.4-4.5)\end{array}$ & \multirow{4}{*}{0.001} & $\begin{array}{l}3.8 \\
(3.28-4.93)\end{array}$ & \multirow{4}{*}{$<0.001$} & $\begin{array}{l}3.8 \\
(3.3-4.7)\end{array}$ & 0.91 \\
\hline Fibrinogen $8 \mathrm{~h}$ & $\begin{array}{l}3.55 \\
(3.2-4.03)\end{array}$ & & $\begin{array}{l}3.7 \\
(3-4.35)\end{array}$ & & $\begin{array}{l}3.6 \\
(3.13-4.1)\end{array}$ & 0.94 \\
\hline Fibrinogen $24 \mathrm{~h}$ & $\begin{array}{l}4.05 \\
(3.43-4.68)\end{array}$ & & $\begin{array}{l}4 \\
(3.35-5.15)\end{array}$ & & $\begin{array}{l}4 \\
(3.45-4.85)\end{array}$ & 0.77 \\
\hline Fibrinogen $48 \mathrm{~h}$ & $\begin{array}{l}4.3 \\
(3.6-5) \\
\end{array}$ & & $\begin{array}{l}4.9 \\
(3.7-5.4) \\
\end{array}$ & & $\begin{array}{l}4.3 \\
(3.7-5.2) \\
\end{array}$ & 0.15 \\
\hline
\end{tabular}

*Friedman's test ${ }^{\dagger}$ Mann Whitney U test; $\mathrm{CRP}=\mathrm{C}$-reactive protein; $\mathrm{EVT}=$ endovascular treatment; $\mathrm{PTA}=$ percutaneous transluminal angioplasty

subgroup compared to PTA subgroup 48 hours following EVT.

Regarding the association between elevation of $\mathrm{CRP}$ and fibrinogen with the extent of periprocedural arterial injury (Table 5), significant positive correlation was found between PTA treated segment length and CRP increase between 8 hours and 24 hours following EVT $(r=0.313, p=0.02)$, between balloon inflation 
Table 5. Correlation between elevation of inflammatory biomarker plasma levels and extent of periprocedural arterial injury

\begin{tabular}{|c|c|c|c|}
\hline & \multicolumn{3}{|c|}{$\begin{array}{l}\text { Spearman's rank correlation } \\
\text { coefficient Rho ( } p \text {-value) }\end{array}$} \\
\hline & $\begin{array}{l}\text { PTA treated } \\
\text { segment } \\
\text { length }\end{array}$ & \begin{tabular}{|l|} 
Balloon \\
inflation \\
time
\end{tabular} & $\begin{array}{l}\text { Stented } \\
\text { segment } \\
\text { length }\end{array}$ \\
\hline $\begin{array}{l}\Delta \mathrm{CRP} \\
(0-8 \mathrm{~h})\end{array}$ & 0.015 & -0.114 & $0.535(0.01)$ \\
\hline $\begin{array}{l}\Delta \mathrm{CRP} \\
(8 \mathrm{~h}-24 \mathrm{~h})\end{array}$ & $0.313(0.02)$ & $0.270(0.03)$ & 0.202 \\
\hline $\begin{array}{l}\Delta \mathrm{CRP} \\
(24 \mathrm{~h}-48 \mathrm{~h})\end{array}$ & 0.109 & -0.035 & -0.011 \\
\hline $\begin{array}{l}\Delta \text { Fibrinogen } \\
(0-8 \mathrm{~h})\end{array}$ & 0.131 & 0.081 & -0.083 \\
\hline $\begin{array}{l}\Delta \text { Fibrinogen } \\
(8 \mathrm{~h}-24 \mathrm{~h})\end{array}$ & -0.059 & -0.117 & 0.173 \\
\hline $\begin{array}{l}\Delta \text { Fibrinogen } \\
(24 \mathrm{~h}-48 \mathrm{~h})\end{array}$ & 0.073 & 0.021 & -0.076 \\
\hline
\end{tabular}

$\mathrm{CRP}=\mathrm{C}$-reactive protein; $\mathrm{PTA}=$ percutaneous transluminal angioplasty

time and CRP increase in the aforementioned time frame $(r=0.270, p=0.03)$, as well as between CRP increase in the first 8 hours following stenting and the stented segment length $(\mathrm{r}=0.535, \mathrm{p}=0.01)$. There was no significant positive correlation between fibrinogen levels and the extent of periprocedural arterial injury.

\section{Discussion}

Endovascular treatment as a minimally invasive therapy treats only the diseased vessel segment. However, dilatation with high-pressure balloons and implantation of stents cause periprocedural injury of the arterial wall by endothelial denudation, as well as intimal and medial damage ${ }^{16}$. These injuries are followed by inflammatory response that often ends with neointimal hyperplasia, a major culprit for long-term EVT failure ${ }^{17}$.

Although CRP and fibrinogen are among the most studied inflammatory biomarkers associated with atherosclerosis, their exact role in the response to arterial injury remains unclear. In the current study, CRP level increase showed positive correlation with PTA treated segment length, balloon inflation time and stented segment length, suggesting that the extent of periprocedural arterial injury correlates with vascular inflammatory response. However, we found no such correlation for fibrinogen. These results are consistent with a previous study of coronary arteries ${ }^{18}$, where postprocedural increase of CRP correlated with the total stented segment length. Conflicting results have been reported from the study performed by Wu et al. ${ }^{19}$, where CRP levels were highest 24 hours after percutaneous coronary intervention, but no statistical difference regarding inflammatory response was found between different dilatation pressures and different stented segment lengths. We found no similar studies assessing the increase in inflammatory biomarkers following EVT on peripheral arteries.

In this study, significant increase was detected in both CRP and fibrinogen levels in patients following EVT. Similar increase in inflammatory biomarkers was found after EVT in previous studies, both on coronary and peripheral arteries ${ }^{4,20-23}$.In the control group, the increase in CRP and fibrinogen levels following angiography was evident, although not statistically significant. That mild increase could be attributed to arterial puncture and contrast media application.

On subgroup analysis, both PTA and stent groups showed statistically significant increase in postprocedural CRP and fibrinogen levels. Plasma CRP levels were found to be significantly higher in patients 48 hours following stent implantation compared to PTA group. These results can be correlated with morphometric studies ${ }^{24,25}$ in porcine models where more intimal hyperplasia was found after stenting compared to balloon angioplasty, suggesting a more pronounced inflammatory response.

The TASC II classification, with its latest update in $2015^{15}$, provides guidelines on optimal treatment modality for PAD based on lesion complexity and location. Although more complex lesions are more difficult to treat, requiring more endovascular manipulation, in our study no significant difference was found in CRP and fibrinogen levels between different lesion complexity assessed by TASC II classification. Previous studies by Schillinger et al..$^{20,22}$ showed no correlation between postprocedural inflammatory response and lesion morphology either.

The present study showed that the arterial injury caused by EVT reflected on the level of inflammatory biomarkers. However, there were several limitations to 
our study. Although the interventions were performed according to the TASC II guidelines, angioplasty balloons and stents, as well as balloon inflation time were determined by the operator. Results could have been influenced by the relatively small number of patients and the concomitant use of various drugs not directly related to atherosclerotic disease. Different diameters, designs and structures of stents could also modulate inflammatory response. There was no follow up to study the correlation of our findings with restenosis rate.

Although the inflammatory nature of atherosclerosis is well known for almost two decades ${ }^{26}$, the role of inflammatory biomarkers has not yet been completely elucidated. The present study assessed the correlation between periprocedural arterial injury and inflammatory response measured by CRP and fibrinogen increase, suggesting that the extent of iatrogenic damage to the arterial wall could relate to future arterial remodeling and subsequent restenosis. Due to the complexity of vascular biology, future studies are warranted to clarify the inflammatory reactions observed.

\section{References}

1. Chiu J-J, Chien S. Effects of disturbed flow on vascular endothelium: pathophysiological basis and clinical perspectives. Physiol Rev. 2011 Jan;91(1):327-87, https://doi.org/10.1152/ physrev.00047.2009

2. Bai H, Masuda J, Sawa Y, Nakano S, Shirakura R, Shimazaki Y, et al. Neointima formation after vascular stent implantation. Spatial and chronological distribution of smooth muscle cell proliferation and phenotypic modulation. Arterioscler Thromb J Vasc Biol. 1994 Nov;14(11):1846-53.

3. Cwikiel W. Restenosis after balloon angioplasty and/or stent insertion - origin and prevention. Acta Radiol. 2002 Sep;43 (5):442-54.

4. Schillinger M, Exner M, Mlekusch W, Rumpold H, Ahmadi $\mathrm{R}$, Sabeti S, et al. Fibrinogen predicts restenosis after endovascular treatment of the iliac arteries. Thromb Haemost. 2002 Jun;87(6):959-65.

5. Schillinger M, Exner M, Mlekusch W, Rumpold H, Ahmadi $\mathrm{R}$, Sabeti S, et al. Vascular inflammation and percutaneous transluminal angioplasty of the femoropopliteal artery: association with restenosis. Radiology. 2002 Oct 1;225(1):21-6, https://doi.org/10.1148/radiol.2251011809

6. Vrsalović M, Vučur K. Diabetes and critical limb ischemia: the deadly duo in patients with symptomatic peripheral artery disease. Acta Clin Croat. 2016 Jun 1;55.(2.):240-5, https://doi. org/10.20471/acc.2016.55.02.09.
7. Calabró P, Willerson JT, Yeh ETH. Inflammatory cytokines stimulated C-reactive protein production by human coronary artery smooth muscle cells. Circulation. 2003 Oct 21;108 (16):1930-2, https://doi.org/10.1161/01.CIR.0000096055.62724.C5.

8. Yasojima K, Schwab C, McGeer EG, McGeer PL. Generation of $\mathrm{C}$-reactive protein and complement components in atherosclerotic plaques. Am J Pathol. 2001 Mar;158(3):1039-51, https://doi.org/10.1016/S0002-9440(10)64051-5.

9. C-Reactive Protein: Reference Range, Interpretation, Collection and Panels. 2017 Jan 7 [cited 2017 Apr 16]; Available from: http://emedicine.medscape.com/article/2086909-overview

10. Huang G, Luo C, Gu X, Wu Z, Wang Z, Du Z, et al. Mechanical strain induces expression of $\mathrm{C}$-reactive protein in human blood vessels. J Pharmacol Exp Ther. 2009 Jul;330(1): 206-11, https://doi.org/10.1124/jpet.109.150961.

11. Smith FB, Lee AJ, Hau CM, Rumley A, Lowe GD, Fowkes FG. Plasma fibrinogen, haemostatic factors and prediction of peripheral arterial disease in the Edinburgh Artery Study. Blood Coagul Fibrinolysis Int J Haemost Thromb. 2000 Jan; 11(1):43-50.

12. Lowe GD, Fowkes FG, Dawes J, Donnan PT, Lennie SE, Housley E. Blood viscosity, fibrinogen, and activation of coagulation and leukocytes in peripheral arterial disease and the normal population in the Edinburgh Artery Study. Circulation. 1993 Jun;87(6):1915-20.

13. Monraats PS, Rana JS, Zwinderman AH, de Maat MPM, Kastelein JP, Agema WRP, et al. -455G/A polymorphism and preprocedural plasma levels of fibrinogen show no association with the risk of clinical restenosis in patients with coronary stent placement. Thromb Haemost. 2005 Mar;93(3):564-9, DOI: 10.1160/TH04-11-0708.

14. Fontaine R, Kim M, Kieny R. [Surgical treatment of peripheral circulation disorders]. Helv Chir Acta. 1954 Dec;21(5-6): 499-533. (in German)

15. TASC Steering Committee, Jaff MR, White CJ, Hiatt WR, Fowkes GR, Dormandy J, et al. An update on methods for revascularization and expansion of the TASC lesion classification to include below-the-knee arteries: a supplement to the InterSociety Consensus for the Management of Peripheral Arterial Disease (TASC II). Vasc Med Lond Engl. 2015 Oct;20(5): 465-78, https://doi.org/10.1177/1358863X15597877.

16. Ross R. The pathogenesis of atherosclerosis - an update. N Engl J Med. 1986 Feb 20;314(8):488-500.

17. O'Brien ER, Schwartz SM. Update on the biology and clinical study of restenosis. Trends Cardiovasc Med. 1994 Jul 1;4(4): 169-78.

18. Kralisz P, Kemona H, Dobrzycki S, Bachórzewska-Gajewska $\mathrm{H}$, Nowak K, Sawicki Z. Changes in C-reactive protein levels following coronary stent implantation depend on the extent of periprocedural arterial injury. Kardiol Pol. 2006 Apr;64(4): 364-71; discussion 372.

19. Wu M, Gu X, Li X, Li Y, Zhou H, Lu G, et al. C-reactive protein and inflammatory cytokines during percutaneous coro- 
nary intervention. J Vasc Res. 2016 Oct 20;53(1-2):39-48, https://doi.org/10.1159/000447558.

20. Schillinger M, Exner M, Mlekusch W, Haumer M, Ahmadi R, Rumpold $\mathrm{H}$, et al. Inflammatory response to stent implantation: differences in femoropopliteal, iliac, and carotid arteries. Radiology. 2002 Aug;224(2):529-35, https://doi.org/10.1148/radiol.2241011253.

21. Araújo PV, Ribeiro MS, Dalio MB, Rocha LA, Viaro F, Joviliano $\mathrm{RD}$, et al. Interleukins and inflammatory markers in instent restenosis after femoral percutaneous transluminal angioplasty. Ann Vasc Surg. 2015 May 1;29(4):731-7, https://doi. org/10.1016/j.avsg.2014.12.006.

22. Schillinger M, Exner M, Mlekusch W, Haumer M, Rumpold $\mathrm{H}$, Ahmadi $\mathrm{R}$, et al. Endovascular revascularization below the knee: 6 -month results and predictive value of $\mathrm{C}$-reactive protein level. Radiology. 2003 May 1;227(2):419-25, https://doi.org/10.1148/radiol.2272020137.
23. Kavitha S, Sridhar MG, Satheesh S. Periprocedural plasma fibrinogen levels and coronary stent outcome. Indian Heart J. 2015;67(5):440-3, https://doi.org/10.1016/j.ihj.2015.06.006.

24. Elesbão JL de L, Pereira AH, Grüdtner MA, Meyer F. Morphometric analysis of swine carotid artery angioplasty with or without cobalt-chromium stent implantation. J Vasc Bras. 2010 Jun;9(2):40-6, http//dx.doi.org/10.1590/S1677-54492010000200006.

25. Castro Júnior C, Pereira AH, Pasa MB. Morphometric analysis of the intimal reaction after stent implantation in iliac arteries submitted to angioplasty in pigs. Acta Cir Bras. 2006 Jun; 21(3):139-43, http//dx.doi.org/10.1590/S0102-86502006000300004.

26. Ross R. Atherosclerosis - an inflammatory disease. N Engl J Med. 1999 Jan 14;340(2):115-26.

Sažetak

\title{
JAČINA UPALNOG ODGOVORA NAKON PERIFERNE ENDOVASKULARNE INTERVENCIJE OVISI O OPSEGU PERIPROCEDURALNOG OŠTEĆENJA ARTERIJSKE STIJENKE
}

\author{
T. Turk, O. Rubin, G. Šarić, T. Mišević, V. Kopačin, D. Kovač, V. Ivković, V. Farkaš i V. Šerić
}

Cilj je bio istražiti postoji li povezanost između poslijeproceduralnog porasta serumske razine C-reaktivnog proteina (CRP) i fibrinogena ovisno o opsegu periproceduralnog oštećenja arterijske stijenke tijekom endovaskularne intervencije. Ispitanici kojima je učinjena dijagnostička angiografija (84 ispitanika) činili su kontrolnu skupinu. Ispitanici kojima je učinjena endovaskularna intervencija na perifernim arterijama (71 ispitanik) činili su eksperimentalnu skupinu. Svakom ispitaniku su prije zahvata te 8, 24 i 48 sati nakon zahvata izmjereni CRP i fibrinogen iz venske krvi. Za svakog su ispitanika bilježeni tip i duljina tretirane lezije, vrijeme inflacije balona te duljina stentiranog segmenta. Značajan porast CRP i fibrinogena uočen je 48 sati nakon intervencije $(\mathrm{p}<0,001)$. Nije bilo značajne razlike u porastu CRP i fibrinogena ovisno o tipu lezije. U skupini bolesnika kojima je postavljen stent 48 sati nakon intervencije uočen je značajan porast CRP, usporedno $s$ ispitanicima kojima je učinjena angioplastika balonom. Nađena je pozitivna povezanost porasta CRP između 8 i 24 sata nakon intervencije i duljine balonom tretiranog segmenta $(r=0,313, p=0,02)$, kao i vremena inflacije balona $(r=0,270, p=0,03)$. Uočena je pozitivna povezanost porasta $\mathrm{CRP}$ prvih 8 sati nakon intervencije i duljine stentiranog segmenta $(\mathrm{r}=0,535, \mathrm{p}=0,01)$. Ovo je istraživanje pokazalo utjecaj opsega periproceduralne lezije arterijske stijenke na poslijeproceduralni porast upalnih biomarkera.

Ključne riječi: C-reaktivni protein; Fibrinogen; Stentovi; Angiografija; Endovaskularni zahvati; Angioplastika 